\title{
Determinant Factors of Money Management among Nigerian Undergraduates
}

\author{
Adebisi Taibat Tunrayo*)1, Salami Oluwatosin Odunayo ${ }^{2}$, Johnson Winifred \\ Oluwaseyi $^{3}$, Arubayi Diana Oritshegbemi ${ }^{4}$ \\ ${ }^{1,2,3}$ Department of Home Economics and Food Science, Faculty of Home Economics \\ and Food Science, University of Ilorin, Ilorin, Nigeria \\ ${ }^{4}$ Department of Vocational Education, Faculty of Education, Delta State University, \\ Abraka, Nigeria
}

*Corresponding author: adebisi.tt@unilorin.edu.ng

\begin{abstract}
The study assessed money management on Nigerian undergraduates at the University of Ilorin, Nigeria. Six research questions and four hypotheses were formulated. Descriptive research of a survey type was adopted. There were 16 faculties with five were selected purposively. The snowball method was used to select the sample size from the total population. A self-structured questionnaire was used to elicit information from the participants. Data collected were analyzed using frequency and percentage, while hypotheses were tested using ANOVA at 0.05 level of significance. Based on the findings, the participants agreed that they had different sources of money to make use of with a grand mean score of 2.83, while the course of study, religious beliefs, relationship status, and lifestyle influenced their money management with grand mean scores 2.80 , $2.56,2.85$ and 2.70 respectively. The research hypotheses depicted the insignificant effect on religious beliefs, lifestyle, and relationship status had on money management, but only the effect of undergraduates' course of study was significant, and thus, the hypothesis was rejected. Conclusively, every undergraduate should apply a good pattern of financial behavior for improvement and sensitize themselves on money appropriateness since they will become future managers and decision-makers that will generate future revenues.
\end{abstract}

Keywords: behavior, consumer, education, management, money

\begin{abstract}
Abstrak
Penelitian ini mengkaji pengelolaan uang pada sarjana Nigeria di University of Ilorin, Nigeria. Enam pertanyaan penelitian dan empat hipotesis dirumuskan. Penelitian deskriptif dari jenis survei digunakan dalam penelitian ini. Dari 16 fakultas dipilih lima fakultas secara purposive. Metode snowball digunakan untuk memilih besar sampel dari total populasi. Kuesioner terstruktur sendiri digunakan untuk memperoleh informasi dari responden. Data yang terkumpul kemudian dianalisis menggunakan frekuensi dan persentase, sedangkan hipotesis diuji dengan ANOVA dengan taraf signifikansi 0.05. Hasil penelitian menunjukkan bahwa responden memiliki sumber uang yang berbeda
\end{abstract}


untuk digunakan dengan skor rata-rata 2.83, sedangkan program studi, keyakinan agama, status hubungan, dan gaya hidup mempengaruhi pengelolaan uang mereka dengan masing-masing rata-rata skor 2.80, 2.56, 2.85 dan 2.70. Hipotesis penelitian menggambarkan pengaruh yang tidak signifikan terhadap keyakinan agama, gaya hidup, dan status hubungan terhadap pengelolaan uang, tetapi hanya pengaruh program studi sarjana yang signifikan, dan dengan demikian hipotesis ditolak. Setiap sarjana harus menerapkan pola perilaku keuangan yang baik untuk perbaikan dan peka terhadap kesesuaian uang karena mereka akan menjadi pengelola keuangan di masa depan dan pengambil keputusan yang akan menghasilkan pendapatan di masa depan.

Kata kunci: konsumen, manajemen, pendidikan, perilaku, uang

\section{Introduction}

Money is an important material resource that individuals use to buy most of the goods and services. The amount of satisfaction we get from the money depends on how we manage it. Money management is an organized process of allocating specified goals that are usually purchased with money. Proper money management is crucial to avoid unnecessary spending, impulse buying, and disappointment in savings. Undergraduates are free to decide on how to spend their allowances, gifts, and donations.

The undergraduates will be the future managers and decision-makers who will generate revenues for the nations. According to Bamforth, Jebarajakirthy, and Geursen (2017); Heenkenda (2014); Atkinson and Kempson (2004) asserted that this action would retain long in terms of financial stability of an organization, industry, and nation. Over the past decades, money is one of the most important aspects of modern-day life as anyone needs money as crucial support in lives to face challenging world conditions. Money has been recognized as a powerful motivator of behavior (Ridhayani \& Johan, 2020).

Over the years, studies reported that some undergraduates lack financial knowledge. Those with high levels of financial knowledge tend to have the right opinions and make correct decisions related to savings, borrowing and investing. It was observed that those with relationships incur more expenses. Also, nowadays, most students grow up under the wings of their parents, adored, spoiled, and with a continuous increase in the availability of materialistic enjoyment, which makes them hold different money attitudes and live a different lifestyle. As a result of their exposure, they tend to buy and spend exorbitantly (Gordon, 2010).

Previous studies revealed that financial literacy influences money management

behavior and the level of influence of money management behavior is on High school students and undergraduates in the university. Their decision relating to money management might also influence their life itself. This can affects the long-term financial stability of any establishments and nation at large. Lusardi and Mitchell (Lusardi \& Mitchell, 2014) also indicated studies on money management attitude. They focused mostly on functional financial literacy, credit card usage, and debt management.

Money management plays an important role in shaping an individual quality of life, social relationships, and mental fitness. It involves managing, minimizing the chance of misleading financial matters, and debts. They take on high levels of personal responsibility and challenges concerning monthly expenses and savings. It is important to equip them in attaining effective money management behavior (Eckwert \& Zilcha, 
2015; Sachitra, Wijesinghe, \& Gunasena, 2019). The lifestyle of spending money to intimidate other colleagues, spending money lavishly to catch fun, or purchase outrageously that they cannot afford or maintain. Similarly, Javine (Javine, 2013) noted that students who come from families with higher socioeconomic status tend to be less risky with their money and often have less need for student loans. Jorgensen and Savla (Jorgensen \& Savla, 2010) found that parental influence had an indirect effect on the money management behavior of every family member. The importance of parental involvement is also very important at an earlier stage of their lives. Therefore, the demand for money management assists undergraduates to be wiser and prudent when spending to avoid wasting money. If planning and management are systematically and efficiently implemented, the financial position will be sufficient and may even have a surplus and can be used as a savings (Rea, Zuiker, \& Mendenhall, 2016).

Therefore, the need to effectively and efficiently utilize money arises as money management has been strongly important. Brigham \& Houston (2014) further noted that the amount of satisfaction gotten from money depends on how well it is managed. On the other hand, the undergraduates that have a weaker ability to manage money appropriately have issues on a decision relating to this might benefit immensely from this study. Irresponsible spending behavior might inhibit good academic performance, social relationships, physical and emotional wellbeing (Lusardi \& Mitchell, 2014). Thus the study is a vital concern to society. Undergraduates sources of money are: from parents, scholarships, loans, bursary, lifestyles, entrepreneurial dealings, monetary gifts, and allowances. Students that can manage their finances are more likely to organize their lives and manage their time in a way conducive to good academic progress. The findings of Zuriana and Rosniyati (2012) reveals that the exposure given to undergraduates concerning money management helps them to become confident, plan, and manage their finances. Money management education plays a key role in financial empowerment, as education helps students acquire the skills, right attitudes, and relevant knowledge needed in making choices for the best of their economy, health, safety, and wellness (Daft, Benson, \& Henry, 2016). So, money management is necessary as it has become essential that students get acts of conscious spending to be able to survive in the future with satisfaction.

Most undergraduates incur a lot of expenses due to the course of study they offered. Some courses involve more practical that increase their spending, some textbooks, and laboratory gadgets are expensive-projects and seminars involved on- for -seen expenses. Hence money management capabilities are essential to undergraduates' personal and academic success. However, a study by Su and Den (Su \& Deng, 2012) found that more than half of the undergraduates can manage their spending and already have saved and storage consciousness, but there were still 12.3 percent of the undergraduates used up their pocket money within two weeks. It was an extravagant and waste phenomenon, which was not advisable. Most of the undergraduates lacked certain planning in money management. They cannot make spending plans very well according to their own needs and ability. Research from Hisyam and Rafi (2016) found a lack of financial awareness and financial planning concepts among today's undergraduates. Prihartono and Asandimitra (2018), opined that every student should apply a good pattern of financial behavior to start implementing money management to make life more meaningful and prosperous. With the increasing significance of money in one's life in the contemporary world, it is important to understand the attitude of people towards money management because it is the money attitude that determines an 
individual (Kowel, 2015; Mottola, 2014; Sachitra \& Bandara, 2017), while Hodson \& Dwyer (2014) researched developed contexts like Australia, New Zealand, USA, and the UK. They examined the interrelationships among economic, social, and psychological factors and their impacts on money management behavior. They studied the undergraduates who have a weaker ability to make the appropriate decision. Mahdzan \& Tabiani (2013) asserted that monthly budgeting expenses, working savings, debt management, and fee payment are very vital. Religion has an enormous influence on people's lives and is closely linked to their economic conditions.

It has been observed that some undergraduates who were in relationships (dating) incur more expenses than other single undergraduates. Being in a relationship increase their expenditures, and planning is not easy, especially if the partner is extravagant in spending. Most university undergraduates nowadays grew up under the wings of their parents, adored and spoiled, and, with a continuous increase in the availability of materialistic enjoyment which makes them hold a different money attitude and live a different lifestyle. As a result of their exposure, they tend to spend exorbitantly. Research has revealed that some of the undergraduates are not very adept at financial management. They lack the discipline of budgeting and are prone to overspending due to their relationship affairs (Archuleta, Dale, \& Spann, 2013). They cannot control impulsive spending and make irrational purchasing decisions due to oppression and impression.

Specifically, six research questions were raised. These are: 1) what were the socioeconomic characteristics of the selected university of Ilorin undergraduates 2) what were the sources of money available to undergraduates 3) what were the effects undergraduates course of study on money management 4) what is the influence of religion on undergraduate money management 5) what impact do the undergraduates' relationship status have on money management 6) what effect do the undergraduates' lifestyles on money management. Four null hypotheses were formulated and tested at

0.05 level of significance. $\mathrm{H}_{1}$ : There was no significant effect of undergraduates' course of study on money management. $\mathrm{H}_{2}$ : There was no significant effect of undergraduates' religion on money management. $\mathrm{H}_{3}$ : There was no significant effect of undergraduates' relationship status on money management. $\mathrm{H}_{4}$ : There was no significant effect of undergraduates' family lifestyle on money management.

\section{Methods}

\section{Participant}

Descriptive research of survey type was used for collecting and gathering data for this research. The study assessed undergraduates' attitudes on money management of selected students at the University of Ilorin, Nigeria. The research was conducted in April 2019 for two weeks with two research assistants. One day was used for the pilot study that 14 copies of the questionnaire were administered, while 11 days, excluding 2 Sundays, were used for field surveys on the distribution of 176 copies of the questionnaire. All the copies of the questionnaire were retrieved.

The unit of analysis of this study was undergraduates that are still pursuing a firstdegree program at the University of Ilorin, Ilorin, Nigeria. There are sixteen faculties in the institution, with five of them purposively selected proportionately at a ratio of 1:3. The total population of the undergraduates in the five faculties was $13.176(2018 / 2019$ session university of Ilorin registrar registration profile). The sample size 
was obtained through snowball sampling techniques. The details of the five faculties sample size breakdown are Arts 33, Agriculture 95, Education 23, Engineering 21, Management Science 18. A total of 190 undergraduates was obtained with 14 undergraduates selected from the faculty of arts from 33 for pilot study, which was not part of the field survey. Therefore, the sample size of 176 participants was used for the field survey.

\section{Measurement}

The questionnaire was a self-developed closed-ended type that restricted response on a 4-point scale ("strongly agree" $=4.0$, "agree" $=3.0$, "strongly disagree" = 2.0 and "disagree" =1.0). The instrument consists of six sections. Section one: is on the socioeconomic characteristics of the participants. Socioeconomic characteristics are the social standing of the participant. It contains 6-items, which include: course of study, age, relationship (dating), religion, lifestyle, and allowance (monthly). The course of study is the subject area that the participant was studying at the university. Age is the whole duration of the participant being alive. Relationship is how two participants talk,

behave toward romantic or sexual friendship. Religion is participant faith through the means that helshe worships God. Lifestyle is a participant way of life. Allowance is money available to the participant for upkeep and wellbeing. It was measured using frequency and percentage (Manikandan, 2011; Sundaram, Dwivedi, \& Sreenivas, 2010).

Section two is sources of money, the means that the participant acquired to realize allowance for upkeep from parents, scholarships, loans, personal savings, e.t.c. The contains 8-statements on the sources of money available to undergraduates, which include; parents, scholarships, loan, bursary, personal savings, entrepreneurial dealing, monetary gifts, and relations. Section three: consists of 6- statements on the course of study. Section four consists of 6-item statements on religion. Section five solicited information on the relationship of the participants, while section six: contains 8statements on the lifestyle of the participants. According to (Kabir, 2013; Kabir, 2016), the 4-Likert scale of strongly agree to strongly disagree can be used to measure sections two to six. The mean rating was used as a decision rule to agree or disagree with the statements. Any score above 2.50 was termed agreed, while any score below 2.50 was termed disagreed. The pilot study was carried out using fourteen copies of the questionnaire for a segment from the faculty of arts for the field survey. The instrument was analyzed, and a reliability coefficient of 0.682 was derived using Cronbach's alpha. This was considered high enough for reliability.

\section{Analysis}

Data were collected in the form of primary data. The primary data were obtained by filling questionnaires that sought information on socioeconomic characteristics, lifestyles, sources of money, course of study, religion, and the relationship of the undergraduates of the University of Ilorin, Nigeria.

Data collected through questionnaire were processed and analyzed using Microsoft excel and SPSS 21 for windows. Editing, coding, entry, scoring, and analysis were used for processing the data. Assessment of money management among Nigerian undergraduates was measured using a 1-4 mean rating score $(1.00+2.00+3.00+4.00=$ $10.00 \div 4.00=2.50)$. 2.50 was the decision rule. Any score less than 2.50 was regarded as disagreed while a score above, is termed agreed. Descriptive statistics of frequency counts, percentages, mean and standard deviation were used to achieve the specific 
objectives while the null hypotheses were tested using Analysis of Variance (ANOVA) at 0.05 level of significance.

\section{Findings}

\section{Undergraduates Socioeconomic Characteristics}

Table 1 shows the socioeconomic information of the participants. The course of study distribution shows that majority: 95 (54.00\%) participants were from the faculty of agriculture, 21-25years of the age of the participants were $112(63.60 \%)$, while 100 $(56.80 \%)$ of the participants were single. Furthermore, $104(59.10 \%)$ participants were Christians, $121(68.80 \%)$ participants lived a moderate lifestyle and received a monthly allowance of $\$ 5,000$ - $\$ 10,000$ (\$12.82 - \$25.64).

Table 1 Distribution of participants by economic information

\begin{tabular}{|c|c|c|c|c|}
\hline $\mathrm{S} / \mathrm{N}$ & Variables & Participants & $\begin{array}{c}\text { Frequency } \\
(\mathrm{f}) \\
(\mathrm{n}=176)\end{array}$ & Percentage (\%) \\
\hline \multirow[t]{5}{*}{1} & \multirow{5}{*}{$\begin{array}{l}\text { Course of } \\
\text { Study }\end{array}$} & Arts & 19 & 10.80 \\
\hline & & Agriculture & 95 & 54.00 \\
\hline & & Education & 23 & 13.10 \\
\hline & & Engineering & 21 & 11.90 \\
\hline & & Management Science & 18 & 10.20 \\
\hline \multirow[t]{4}{*}{2} & \multirow[t]{4}{*}{ Age } & 15 -20years & 40 & 22.70 \\
\hline & & 21-25years & 112 & 63.60 \\
\hline & & 26-30years & 21 & 11.90 \\
\hline & & 31 and above & 3 & 1.70 \\
\hline \multirow[t]{4}{*}{3} & \multirow{4}{*}{$\begin{array}{l}\text { Relationship } \\
\text { (dating) }\end{array}$} & Single & 100 & 56.80 \\
\hline & & In a relationship & 63 & 35.80 \\
\hline & & Engaged & 7 & 4.00 \\
\hline & & Married & 6 & 3.40 \\
\hline \multirow[t]{3}{*}{4} & \multirow[t]{3}{*}{ Religion } & Islam & 69 & 39.20 \\
\hline & & Christianity & 104 & 59.10 \\
\hline & & Traditional & 3 & 1.70 \\
\hline \multirow[t]{3}{*}{5} & \multirow[t]{3}{*}{ Lifestyle } & Low & 40 & 22.70 \\
\hline & & Moderate & 121 & 68.80 \\
\hline & & Extravagant & 15 & 8.50 \\
\hline \multirow[t]{6}{*}{6} & \multirow{6}{*}{$\begin{array}{l}\text { Allowance } \\
\text { monthly }\end{array}$} & $\$ 5000-10000(\$ 12.82-\$ 25.64)$ & 72 & 40.90 \\
\hline & & $\$ 11000-15000(\$ 28.21-\$ 38.46)$ & 46 & 26.10 \\
\hline & & $\$ 16000-20000(\$ 41.02-\$ 51.28)$ & 22 & 12.50 \\
\hline & & 丹21000-25000 (\$53.85- \$64.10) & 12 & 6.80 \\
\hline & & $\$ 26000-30000(\$ 66.67-\$ 76.92)$ & 15 & 8.50 \\
\hline & & $>¥ 31000(\$ 79.49)$ & 9 & 5.10 \\
\hline
\end{tabular}

Source: Field Survey, 2019; Note: S/N= Serial/Number, f = Frequency, N= Sample size

\section{Undergraduates Sources of Money}

Table 2 reveal sources of money available to the participants. Due to the different perception of individuals, the sources of money available to participants are from parents ( $\square=3.45)$, personal savings $(\bar{\square}=3.23)$, entrepreneurial dealings $(\bar{\square}=3.14)$, monetary gifts $(\bar{\square}=2.96)$ and relations $(\bar{\square}=3.19)$. On the contrary, the data reveals that the participants disagreed that scholarships $(\bar{\square}=2.28)$, loan $(\bar{\square}=2.07)$ and bursary $(\bar{\square}=2.33$ ) are the major sources of their money. The grand mean of 2.83 
indicates that there are various sources of money available for the undergraduates since the grand mean is greater than the decision rule $(\bar{\square}=2.50)$.

Table 2 Distribution of participants by sources of money available

\begin{tabular}{|c|c|c|c|c|c|c|c|}
\hline $\mathrm{S} / \mathrm{N}$ & Sources & $\begin{array}{l}\text { SA } \\
\mathrm{f}(\%)\end{array}$ & $\begin{array}{c}\mathrm{A} \\
\mathrm{f}(\%)\end{array}$ & $\begin{array}{c}\mathrm{D} \\
\mathrm{f}(\%)\end{array}$ & $\begin{array}{l}\text { SD } \\
\mathrm{f}(\%)\end{array}$ & $\bar{\square}$ & Remarks \\
\hline 1. & Parents & $97(55.1)$ & $68(38.6)$ & $5(2.8)$ & $6(3.4)$ & 3.45 & Agree \\
\hline 2. & Scholarships & $12(6.8)$ & $61(34.7)$ & $69(39.2)$ & $13(7.4)$ & 2.28 & Disagree \\
\hline 3. & Loan & $13(7.4)$ & $37(21.0)$ & $76(43.2)$ & $50(28.4)$ & 2.07 & Disagree \\
\hline 4. & Bursary & $18(10.2)$ & $61(34.7)$ & $59(33.5)$ & $38(21.6)$ & 2.33 & Disagree \\
\hline 5. & Personal Savings & $68(38.6)$ & $90(51.1)$ & $10(5.7)$ & $8(4.5)$ & 3.23 & Agree \\
\hline 6. & $\begin{array}{l}\text { Entrepreneurial } \\
\text { dealings }\end{array}$ & $62(35.2)$ & $83(47.2)$ & $25(14.2)$ & $6(3.4)$ & 3.14 & Agree \\
\hline 7. & Monetary gifts & $37(21.0)$ & $\begin{array}{c}104 \\
(59.1)\end{array}$ & $27(15.3)$ & $8(4.5)$ & 2.96 & Agree \\
\hline 8. & Relations & $73(41.5)$ & $78(44.3)$ & $12(6.8)$ & $13(7.4)$ & 3.19 & Agree \\
\hline \multicolumn{6}{|c|}{ Grand Mean } & 2.83 & \\
\hline
\end{tabular}

Source: Field Survey, 2019. *Mean $\geq 2.5=$ Agreed, Mean < 2.5; Note: $\mathrm{S} / \mathrm{N}=$ Serial/Number, SA=Strongly Agree, A=Agree, $\mathrm{D}=$ Disagree, $\mathrm{SD}=$ Strongly Disagree, $\mathrm{f}=$ frequency, $\bar{\square}=$ mean, $\%=$ Percentage

\section{Undergraduates Course of Study}

Table 3 reveals the influence of the participant's course of study on money management. The data indicates the opinion of the participants in favor of the statement that their courses involve more practical courses which make them spend more money ( $\bar{\square}$ =3.26). Item 2 reveals that the participants tend to mismanage money due to lack of knowledge on budgeting ( $\bar{\square}=2.89$ ). Also, it was revealed in item 3 that most textbooks and other materials are expensive to purchase $(\bar{\square}=2.72)$.

Table 3 Influence of course of study on money management by the participants

\begin{tabular}{|c|c|c|c|c|c|c|c|}
\hline $\mathrm{S} / \mathrm{N}$ & Statements & $\begin{array}{l}\text { SA } \\
\mathrm{f}(\%)\end{array}$ & $\begin{array}{l}\text { A } \\
f(\%)\end{array}$ & $\begin{array}{l}\mathrm{D} \\
\mathrm{f}(\%)\end{array}$ & $\begin{array}{l}\text { SD } \\
\mathrm{f}(\%)\end{array}$ & $\square^{-}$ & Remark \\
\hline 1. & $\begin{array}{l}\text { The courses involved more } \\
\text { practical sessions which } \\
\text { increased spending. }\end{array}$ & $\begin{array}{l}82 \\
(46.6)\end{array}$ & $\begin{array}{l}63 \\
(35.8)\end{array}$ & $\begin{array}{l}26 \\
(14.8)\end{array}$ & $\begin{array}{l}5 \\
(2.8)\end{array}$ & 3.26 & Agree \\
\hline 2. & $\begin{array}{l}\text { Mismanagement of money due to } \\
\text { lack of knowledge on budgeting. }\end{array}$ & $\begin{array}{l}29 \\
(16.5)\end{array}$ & $\begin{array}{l}109 \\
(61.9)\end{array}$ & $\begin{array}{l}29 \\
(16.5)\end{array}$ & $\begin{array}{l}9 \\
(5.1)\end{array}$ & 2.89 & Agree \\
\hline 3. & $\begin{array}{l}\text { Some textbooks are expensive to } \\
\text { purchase. }\end{array}$ & $\begin{array}{l}34 \\
(19.3)\end{array}$ & $\begin{array}{l}75 \\
(42.6)\end{array}$ & $\begin{array}{l}52 \\
(29.5)\end{array}$ & $\begin{array}{l}15 \\
(8.5)\end{array}$ & 2.72 & Agree \\
\hline 4. & $\begin{array}{l}\text { Projects and seminars involve } \\
\text { impulse spending. }\end{array}$ & $\begin{array}{l}44 \\
(25)\end{array}$ & $\begin{array}{l}61 \\
(35.2)\end{array}$ & $\begin{array}{l}62 \\
(35.2)\end{array}$ & $\begin{array}{l}9 \\
(5.1)\end{array}$ & 2.79 & Agree \\
\hline 5. & $\begin{array}{l}\text { Management sciences } \\
\text { undergraduates are more } \\
\text { conscious about money } \\
\text { management than their } \\
\text { counterparts. }\end{array}$ & $\begin{array}{l}27 \\
(15.3)\end{array}$ & $\begin{array}{l}68 \\
(38.6)\end{array}$ & $\begin{array}{l}62 \\
(35.2)\end{array}$ & $\begin{array}{l}19 \\
(10.8)\end{array}$ & 2.58 & Agree \\
\hline 6. & $\begin{array}{l}\text { More expenses incurred on } \\
\text { excursion/field trips }\end{array}$ & $\begin{array}{l}26 \\
(14.8)\end{array}$ & $\begin{array}{l}74 \\
(42)\end{array}$ & $\begin{array}{l}58 \\
(33)\end{array}$ & $\begin{array}{l}18 \\
(10.2)\end{array}$ & 2.61 & Agree \\
\hline Granc & Mean & & & & & 2.80 & \\
\hline
\end{tabular}

Furthermore, item 4 revealed the opinion of the participants that the high impulse spending on projects and seminars $(\bar{\square}=2.79)$. Also, item 5 revealed that undergraduates of management sciences are more cautious on money management than their counterparts $(\bar{\square}=2.58)$ and also indicates that the participants signified that they incurred more expenses on excursion/field trips with $(\bar{\square}=2.61)$. 


\section{Undergraduates Religion}

Table 4 reveals the effect of religion on money management. Item 1 indicates that most participants disagreed on for seen expenses given out to the needy at a mean value of 2.30. Item 2 reveals that the majority of the participants disagreed that tithes, donations, and offerings given to the needy increases their budget deficit at a mean value of 2.32. Also, it was revealed in item 3 that participant's religious belief makes them accountable for every money spent at mean value 2.59 .

Table 4 Influence of religion on money management by the participants

\begin{tabular}{|c|c|c|c|c|c|c|c|}
\hline $\mathrm{S} / \mathrm{N}$ & Statements & $\begin{array}{c}\text { SA } \\
\mathrm{f}(\%)\end{array}$ & $\begin{array}{c}\mathrm{A} \\
\mathrm{f}(\%)\end{array}$ & $\begin{array}{c}\mathrm{D} \\
\mathrm{f}(\%)\end{array}$ & $\begin{array}{c}\mathrm{SD} \\
\mathrm{f}(\%)\end{array}$ & $\bar{\square}$ & Agree \\
\hline 1. & $\begin{array}{l}\text { Unforeseen expenses are } \\
\text { given out to the needy. }\end{array}$ & $\begin{array}{c}29 \\
(16.5)\end{array}$ & $\begin{array}{c}31 \\
(17.6)\end{array}$ & $\begin{array}{c}81 \\
(46)\end{array}$ & $\begin{array}{c}35 \\
(19.9)\end{array}$ & 2.30 & Disagree \\
\hline 2. & $\begin{array}{l}\text { Donationslofferings } \\
\text { given out increases } \\
\text { budget deficit }\end{array}$ & $\begin{array}{c}11 \\
(6.3)\end{array}$ & $\begin{array}{c}61 \\
(34.7)\end{array}$ & $\begin{array}{c}78 \\
(44.3)\end{array}$ & $\begin{array}{c}26 \\
(14.8)\end{array}$ & 2.32 & Disagree \\
\hline 3. & $\begin{array}{l}\text { The assistance of } \\
\text { accountability in the } \\
\text { money given out. }\end{array}$ & $\begin{array}{c}27 \\
(15.3)\end{array}$ & $\begin{array}{c}62 \\
(35.2)\end{array}$ & $\begin{array}{c}76 \\
(43.2)\end{array}$ & $\begin{array}{c}11 \\
(6.3)\end{array}$ & 2.59 & Agree \\
\hline 4. & $\begin{array}{l}\text { Religious upbringing } \\
\text { influences conscious } \\
\text { money planning. }\end{array}$ & $\begin{array}{c}19 \\
(10.8)\end{array}$ & $\begin{array}{c}111 \\
(63.1)\end{array}$ & $\begin{array}{c}32 \\
(18.2)\end{array}$ & $\begin{array}{l}14 \\
(8)\end{array}$ & 2.76 & Agree \\
\hline 5. & $\begin{array}{l}\text { Money planning helps } \\
\text { during spending }\end{array}$ & $\begin{array}{c}28 \\
(15.9)\end{array}$ & $\begin{array}{c}78 \\
(44.3)\end{array}$ & $\begin{array}{c}60 \\
(34.1)\end{array}$ & $\begin{array}{c}10 \\
(5.7)\end{array}$ & 2.70 & Agree \\
\hline 6. & $\begin{array}{l}\text { Religious belief forbids } \\
\text { extravagant spending. }\end{array}$ & $\begin{array}{c}42 \\
(23.9)\end{array}$ & $\begin{array}{c}69 \\
(39.2)\end{array}$ & $\begin{array}{c}36 \\
(20.5)\end{array}$ & $\begin{array}{c}29 \\
(16.5)\end{array}$ & 2.70 & Agree \\
\hline Gran & Mean & & & & & 2.56 & \\
\hline
\end{tabular}

Furthermore, item 4 revealed that religious upbringing influences money management at a mean value of 2.76 , and item 5 reveals that religious belief helps in money planning during spending at a mean value of 2.70. Finally, it was revealed that the respondent's religious belief forbids spending extravagantly at a mean value of 2.70 .

\section{Undergraduates Relationship Status}

Table 5 reveals the effect of relationship status on money management. Item 1 reveals that most participants agreed that being in a relationship increases their expenditure at a mean value of 3.19. Item 2 indicates that the majority of the participants tend to have a good cash balance due to loyalty to one partner at a mean value of 2.72 . Also, it shows in item 3 that multiple relationships are a critical factor that makes undergraduates run out of cash easily at a mean value of 3.0. Furthermore, item 4 revealed that undergraduates make all possible efforts to abstain from relationships in other to curb excess spending at a mean value of 2.69. Also, item 5 revealed that majority of the respondent's partner makes them spend more than their friends who are without any partner as a mean value of 2.65 and it shows a mean value of 2.88 which signifies that married undergraduates are cautious of money spent. 
Table 5 Influence of relationships on money management by the participants

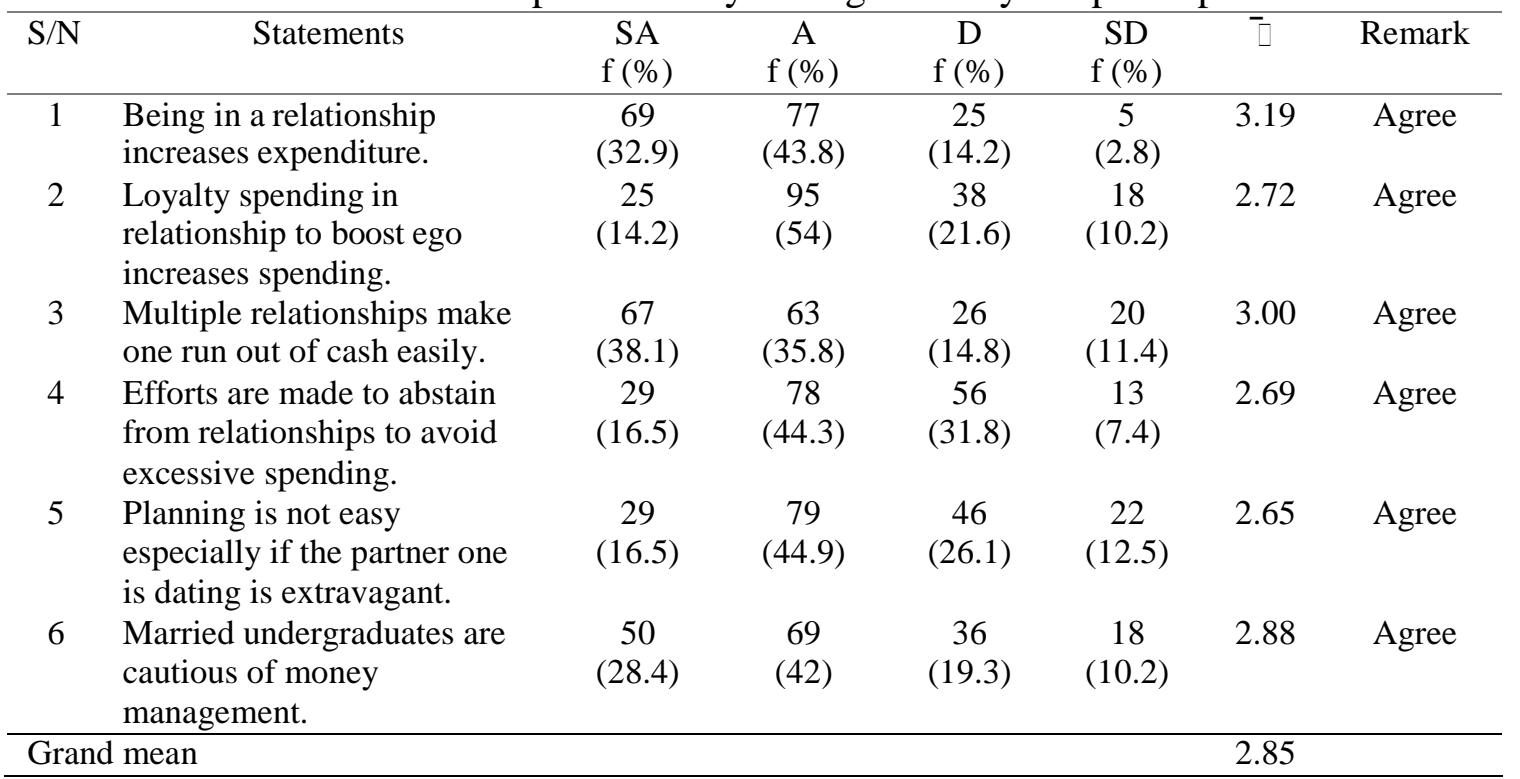

Source: Field Survey, 2019. *Mean $\geq 2.5=$ Agreed, Mean < 2.5; Note: $\mathrm{S} / \mathrm{N}-$ Serial Number, SA=Strongly Agree, A=Agree, D=

Disagree, $\mathrm{SD}=$ Strongly Disagree, $\mathrm{f}=$ frequency, $\square=$ mean, $\%=$ Percentage

\section{Influence of Undergraduates Lifestyles on Money Management}

Table 6 reveals the findings on the influence of an undergraduate's lifestyle that most participants disagreed that they purchase things to intimidate their colleagues.

Table 6 Influence of lifestyle on money management by the participants

\begin{tabular}{|c|c|c|c|c|c|c|c|}
\hline $\mathrm{S} / \mathrm{N}$ & Statements & $\begin{array}{l}\text { SA } \\
\mathrm{f}(\%)\end{array}$ & $\begin{array}{c}\mathrm{A} \\
\mathrm{f}(\%)\end{array}$ & $\begin{array}{c}\mathrm{D} \\
\mathrm{f}(\%)\end{array}$ & $\begin{array}{l}\mathrm{SD} \\
\mathrm{f}(\%)\end{array}$ & Mean & Remarks \\
\hline 1. & $\begin{array}{l}\text { Purchasing things to } \\
\text { intimidate colleagues }\end{array}$ & $34(19.3)$ & $31(17.6)$ & $72(40.9)$ & $39(22.2)$ & 2.34 & Disagree \\
\hline 2. & $\begin{array}{l}\text { Enjoy spending money } \\
\text { lavishly to catch fun. }\end{array}$ & $13(7.4)$ & $67(38.1)$ & $69(39.2)$ & $27(15.3)$ & 2.37 & Disagree \\
\hline 3. & $\begin{array}{l}\text { Saving money to cover for } \\
\text { unforeseen circumstances }\end{array}$ & $51(29)$ & $88(50)$ & 31 (17.6) & $6(3.4)$ & 3.04 & Agree \\
\hline 4. & $\begin{array}{l}\text { Spending irrationally due to } \\
\text { the purchase of standard } \\
\text { goods at once }\end{array}$ & $33(18.8)$ & $87(49.4)$ & $40(22.7)$ & $16(9.1)$ & 2.77 & Agree \\
\hline 5. & $\begin{array}{l}\text { Interest in fashionable } \\
\text { items makes one live above } \\
\text { one's means }\end{array}$ & $26(14.8)$ & $43(24.4)$ & 79 (44.9) & 28 (15.9) & 2.38 & Disagree \\
\hline 6. & $\begin{array}{l}\text { Most times undergraduates } \\
\text { buy outrageous things and } \\
\text { live an extravagant life they } \\
\text { can't afford }\end{array}$ & $48(27.3)$ & $80(45.5)$ & $34(19.3)$ & $14(8)$ & 2.92 & Agree \\
\hline 7. & $\begin{array}{l}\text { Problematic accumulation } \\
\text { of debt has consistently } \\
\text { been linked to drinking, } \\
\text { and hard drug consumption }\end{array}$ & 35 (19.9) & $77(43.8)$ & $42(23.9)$ & $22(12.5)$ & 2.71 & Agree \\
\hline 8. & $\begin{array}{l}\text { Peer group influence affect } \\
\text { undergraduate spending } \\
\text { behavior }\end{array}$ & 70 (39.8) & $68(39.8)$ & $22(12.5)$ & $16(9)$ & 3.09 & Agree \\
\hline \multicolumn{5}{|c|}{ Grand mean } & \multicolumn{3}{|c|}{2.70} \\
\hline
\end{tabular}


Item 2 revealed that the majority of the participants do not enjoy spending money lavishly to catch fun, as a mean value of 2.37 was determined. On the contrary, in item 4 a mean value of 3.04 was realized, which signified that most of the participants like saving money to cover for unforeseen circumstances. Also, it was revealed in item 4 that most participants signified that they spent most times irrationally due to the purchase of standard goods at once, as a mean value, 2.77 was realized. Furthermore, item 5 revealed that participants' interest in fashionable items makes them live above their means as a mean value of 2.38 was realized. Also, item 6 reveals that Most times, participants buy outrageous things and live an extravagant life we can't afford as a mean value of 2.92 was determined.

\section{Influence of Undergraduates Course of Study on Money Management}

Table 7 shows the ANOVA result of participants on the difference between the course of study and money management. The table showed that an F value of 5.131 and a p-value of 0.001 were obtained with a degree of freedom 175 . The null hypothesis was rejected since the p-value of 0.001 was lesser than 0.05 , which indicates that there was a significant effect of the course of study on money management. This implied that the opinion of participants from different course disciplines varies.

Table 7 ANOVA analysis on the course of study on money management by the participants

\begin{tabular}{lcccccc}
\hline & $\begin{array}{c}\text { Sum of } \\
\text { Squares }\end{array}$ & Df & Mean Square & $f$ & Sig. & Remark \\
\hline Between Groups & 149.661 & 4 & 37.415 & & & Rejected \\
Within Groups & 1246.834 & 171 & 7.291 & 5.131 & $0.001 * *$ & Red \\
Total & 1396.494 & 175 & & & & \\
\hline Note: $p>0.01$, Df= Degree of Freedom, $f=$ Frequency, Sig = Significance
\end{tabular}

\section{Influence of Undergraduates Religion on Money Management}

Table 8 shows the ANOVA result of religion difference in money management in which an $F$ value of 0.385 was derived with a p-value of 0.681 , with a degree of freedom 175 at 0.05 level of significance. The null hypothesis was accepted since the p-value of 0.681 was greater than 0.05 , which indicates that there is no significant effect of religion on money management. This implied that the opinion of undergraduates from different religious beliefs does not vary towards money management.

Table 8 ANOVA analysis of religion on money management by the participants

\begin{tabular}{|c|c|c|c|c|c|c|}
\hline & $\begin{array}{l}\text { Sum of } \\
\text { Squares }\end{array}$ & Df & $\begin{array}{l}\text { Mean } \\
\text { Square }\end{array}$ & $f$ & Sig. & Remark \\
\hline Between Groups & 8.676 & 2 & 4.338 & & & \\
\hline Within Groups & 1951.682 & 173 & 11.281 & 0.385 & 0.681 & Accepted \\
\hline Total & 1960.358 & 175 & & & & \\
\hline
\end{tabular}

Note: $\mathrm{Df}=$ Degree of Freedom, $f=$ Frequency, Sig $=$ Significance

\section{Influence of Undergraduates Relationship Status on Money Management}

Table 9 shows the ANOVA result on relationship status difference among undergraduates towards money management in which $\mathrm{F}$ value of .137 was derived with a p-value of 0.938 , with a degree of freedom 175 at 0.05 level of significance. The null hypothesis was accepted since the p-value of 0.938 was greater than 0.05 , which indicates that there is no significant effect of the relationship status of undergraduates 
on money management. This implied that the opinion of undergraduates in different relationships does not vary among them towards money management.

Table 9 ANOVA analysis of relationship status on money management by the participants

\begin{tabular}{lcccccc}
\hline & Sum of Squares & Df & $\begin{array}{c}\text { Mean } \\
\text { Square }\end{array}$ & $f$ & Sig. & Remark \\
\hline Between Groups & 3.924 & 3 & 1.308 & \multirow{2}{*}{0.137} & \multirow{2}{*}{0.938} & \multirow{2}{*}{ Accepted } \\
Within Groups & 1639.622 & 172 & 9.533 & & & \\
Total & 1643.545 & 175 & & &
\end{tabular}

\section{Influence of Undergraduates lifestyle on Money Management}

Table 10 shows the ANOVA analysis on lifestyle on the participants towards money management in which F-value of 2.358 was derived with a p-value of 0.098 , with a degree of freedom 175 at 0.05 level of significance. The null hypothesis was accepted since the p-value of 0.098 was greater than 0.05 , which indicates that there is no significant lifestyle difference among the participants toward money management. This implied that the opinion of undergraduates embracing different lifestyles does not vary among undergraduates towards money management.

Table 10 ANOVA analysis of lifestyle on money management by the participants

\begin{tabular}{lcccccc}
\hline & $\begin{array}{c}\text { Sum of } \\
\text { Squares }\end{array}$ & Df & $\begin{array}{c}\text { Mean } \\
\text { Square }\end{array}$ & $f$ & Sig. & Remark \\
\hline Between Groups & 71.130 & 2 & 35.565 & \multirow{2}{*}{2.358} & 0.098 & Accepted \\
Within Groups & 2609.319 & 173 & 15.083 & & & \\
Total & 2680.449 & 175 & & & &
\end{tabular}

\section{Discussion}

From a conceptual view, over the past decades, money is one of the most important aspects of modern-day life as students need money as crucial support in their lives to face challenging world conditions. Money has been recognized as a powerful motivator of behavior. The current life and financial needs of schools and institutions of higher learnings are very different. This is because the current financial needs of higher education institutions are much higher than those required at the school level (Eckwert \& Zilcha, 2015). Hence the need to effectively and efficiently utilize money arises as money management has been strongly important for undergraduates in an educational environment.

As education help, students acquire skills, right attitudes, and relevant knowledge needed in making choices for the best of their economic, health, and safety wellness (Daft et al., 2016). So, money management is necessary as it has become essential that students get the skills to be able to survive in the future with satisfaction. Meanwhile, student money management was referred to as the behaviors and perception of how students manage their finances and handling their money while studying.

The participants agreed on sources of money from parents, personal savings, entrepreneurial dealings, monetary gifts from relation. Javine (Javine, 2013) noted that undergraduates from higher economic status need fewer loans. Graves and Savage (Graves \& Savage, 2015) attributed their savings knowledge and behavior to parental 
influence. According to Nurhayati and Muflikhati (Nurhayati, \& Muflikhati, 2020), asserted that in managing family resources, the family carries out activities to organize and make decisions. Each family member who has more control in deciding family decisions. Since all parents do not involve their children in decision making, the most fortunate ones will be better in decision making anywhere they find themselves.

The influence of the course of study was weighed using items such as practical courses, textbook purchases, budgeting know-how, projects and seminars, excursions, and field trips. One could infer that the course of study of respective undergraduates had a major influence on their money management. However, management sciences undergraduates were more conscious of managing their finances due to the exposure based on their course of study.

The study indicated that although religious beliefs encouraged accountability, tithes, generous donations and offerings do not create budget deficits. It was deduced that some religious beliefs forbade extravagant spending and, thus, helping many to plan during spending. Also, the religious upbringing of the respondents strongly influenced undergraduates' money management (Alderman, Forsyth, \& Walton, 2017; Du, Du, Zeng, Pei, \& Chang, 2016).

The effect of being relationships increased spending and reduced effective money management, but respondents agreed that faithfully staying with one partner at a time without multiple partners helped in reducing the cost of being in relationships. However, some undergraduates lack the discipline of budgeting and are prone to overspending due to their relationship affairs (Archuleta et al., 2013). Mahdzan and Tabiani (2013) asserted that monthly budgeting expenses, debt management, and fees payments are very vital. Thus, undergraduates are encouraged to make all possible efforts to refrain from relationships in other to curb excess spending as only married undergraduates were observed to be used to these scenarios due to their cautious spending.

The term "lifestyle" stems from the fields of psychology and sociology, referring to a person's particular way of living, and has been used primarily for examining the living patterns and mobility of the various social classes. Undergraduates with different lifestyles hold different money attitudes, and this will often influence purchase decision making as well. Lifestyle changes quite rapidly that influence self - identity. According to McNair, Summers, de Bruin, and Ranyard (2016) opined that a person's self- concept motivates identity-related behaviors and influences behavioral decisions. Other than that, Liyanage, Kumara, and Withanawasam (2017); Sachitra et al., (2019), identified selfidentity as a major predictor of money management behavior in developing countries. The way undergraduates react to financial pressure, spending money on fashionable items, spend money lavishly, and failure to mitigate emotional stress may push them toward borrowing to address financial constraints as well as facilitate further spending. It is very crucial to avoid emotional stress (Pham, Yap, \& Dowling, 2012). Ksendzova, Donnelly, and Howell (Ksendzova, Donnelly, \& Howell, 2017) asserted that some undergraduates express overconfidence in buying new products leading to misleading and impulse buying. Those with an external locus of control are more likely to express greater borrowing than those who have a keen interest in encouraging healthy money management.

Money management needs to be stressed among undergraduates so that they would not be faced with critical financial problems. This indicates that the students need to have a positive attitude, behaviors, and knowledge in managing money so that 
financial problems do not impinge on them in the future (Khamis, Janor, \& Yakob, 2015). Zuriana et al. (2012) revealed that the exposure given to undergraduates in relation to money management assists them to become confident, plan, and manage their finances when needed. There was no limitation during and after the research work due to location and no financial assistance demanded from anybody nor organization.

\section{Conclusion and Recommendations}

\section{Conclusion}

Participants' sources of money available are from; parents, personal savings, entrepreneurial dealings, monetary gifts, and allowances from friends, governmental, and non-governmental agencies. Those that can manage their finances adequately are probably going to compose their lives properly and are likely to live a decent scholastic environment that will be meaningful. Therefore, significantly, it can be concluded from the study that opinions of the participants on the course of study relating to money management varies. This means that there was a significant difference between the course of study and money management. On religion, relationships, and lifestyles, there were no significant differences in their money management based on the findings.

\section{Recommendations}

Based on the findings made in this study, it is therefore recommended that:

1. Seminars and workshops can be organized to sensitize the undergraduates more on money management.

2. Curriculum planners can also include the concept of money management in the school curriculum regardless of the course of study to improve theirknowledge.

3. Parents must inculcate money management habits in their children/wards as they are the major influencers of their lives.

4. This study can serve as a guideline for future research. Therefore, for further research, the focus can be on other variables not included in this study. This should be replicated using male or female undergraduates in other tertiary institutions. In addition, a comparative study of male and female money management can be studied.

\section{References}

Alderman, J., Forsyth, J., \& Walton, R. (2017). How Religious Beliefs Influence Financial Decision-Making. Graziadio Business Review.

Archuleta, K. L., Dale, A., \& Spann, S. M. (2013). College students and financial distress: Exploring debt, financial satisfaction, and financial anxiety. Journal of Financial Counseling and Planning, 24(2), 50-52.

Atkinson, A., \& Kempson, E. (2004). Young people, money management, borrowing and saving A report to the Banking Code Standards Board. pfrc.bris.ac.uk. Retrieved from http://www.pfrc.bris.ac.uk/Reports/BCSB_young_people.pdf

Bamforth, J., Jebarajakirthy, C., \& Geursen, G. (2017). Undergraduates' responses to factors affecting their money management behaviour: some new insights from a qualitative study. Young Consumers, 18(2), 290-311. https://doi.org/10.1108/YC11-2016-00645 
Brigham, E., \& Houston, J. (2014). Essentials of financial management (Third Edition) Singapore: Cengage Learning.

Daft, R., Benson, A., \& Henry, B. (2016). Management (2nd Editio). USA: Cengage Learning. Retrieved from https://www.alibris.com/Management-Richard-LDaft/book/4141059

Du, X., Du, Y., Zeng, Q., Pei, H., \& Chang, Y. (2016). Religious atmosphere, law enforcement, and corporate social responsibility: Evidence from China. Asia Pacific Journal of Management, 33, 229-265. https://doi.org/10.1007/s10490-015- 9441-0

Eckwert, B., \& Zilcha, I. (2015). Higher Education Financing. In The Economics of Screening and Risk Sharing in Higher Education. https://doi.org/10.1016/b978-012-803190-2.00005-4

Gordon, L. (2010). Financial Anxieties Burden More Freshmen, Study Finds, p. 5. Retrieved from https://www.pressreader.com/usa/los-angelestimes/20100121/281578056793718

Graves, E., \& Savage, S. (2015). Financial Pasts, Presents, and Futures of Community College Students of a Personal Finance Course. Journal of Business and Finance Librarianship, 20(1), 116-132. https://doi.org/10.1080/08963568.2015.977132

Heenkenda, S. (2014). Inequalities in the Financial Inclusion in Sri Lanka: An Assessment of the Functional Financial Literacy. MPRA Paper, (67293). Retrieved from

https://www.researchgate.net/publication/281409218_Inequalities_in_the_Financia 1_Inclusion_in_Sri_Lanka_An_Assessment_of_the_Functional_Financial_Literacy Hisyam, M., \& Rafi, I. M. (2016). A Study on Financial Management among Students. Research Hub, 2(1), 75-79. ISSN: 2180-0065.

Hodson, R., \& Dwyer, R. E. (2014). Financial Behavior, Debt, and Early Life Transitions: Insights from the National Longitudinal Survey of Youth, 1997 Cohort. Ohio.

Javine, V. (2013). Financial knowledge and student loan usage in college students. Financial Services Review.

Jorgensen, B. L., \& Savla, J. (2010). Financial literacy of young adults: The importance of parental socialization. Family Relations, 59(4), 465-478. https://doi.org/10.1111/j.1741-3729.2010.00616.x

Kabir, S, M, S. (2013). Positive attitude can change life. Journal of Chittagong, University Teachers Association, 7(1), 55-58.

Kabir, S, M, S. (2016). Measurement Concept: Variables, Reliability, Validity and Norm. In Basic Guidelines for Research: An Introduction Approach for all Disciplines (First, pp. 72-110). Bangladesh: Chittagong-4203.

Khamis, n. A., Janor, H., \& Yakob, R. (2015). Tahap Literasi Kewangan dalam Kalangan Pelajar Universiti Awam: Kajian di Universiti Kebangsaan Malaysia. Jurnal Personalia Pelajar.

Kowel, C. A. (2015). The Influence of Personality, Lifestyle, Money Attitude on Customer Purchase Decision (Case Study: Manado Grand Palace Convention Hall). Jurnal Berkala Ilmiah Efisiensi, 15(5), 417-425. Retrieved from https://ejournal.unsrat.ac.id/index.php/jbie/article/view/9850

Ksendzova, M., Donnelly, G. E., \& Howell, R. T. (2017). A Brief Money Management Scale and Its Associations With Personality, Financial Health, and Hypothetical Debt Repayment. Journal of Financial Counseling and Planning, 28(1), 62-75. 
https://doi.org/10.1891/1052-3073.28.1.62

Liyanage, P. T. D., Kumara, U. A., \& Withanawasam, M. K. P. (2017). Employability Survey of the Management Graduates in Sri Lanka. Retrieved from http://dr.lib.sjp.ac.lk/handle/123456789/5514

Lusardi, A., \& Mitchell, O. S. (2014). The economic importance of financial literacy: Theory and evidence. Journal of Economic Literature, 5(1), 5-44. https://doi.org/10.1257/jel.52.1.5

Mahdzan, N. S., \& Tabiani, S. (2013). The impact of financial literacy on individual saving: An exploratory study in the Malaysian context. Transformations in Business and Economics, 12(1), 41-55.

Manikandan, S. (2011). Frequency Distribution. Journal of Pharmacology and Pharmacotherapeutics, 2(1), 54-55.

McNair, S., Summers, B., de Bruin, W. B., \& Ranyard, R. (2016). Individual-level factors predicting consumer financial behavior at a time of high pressure. Personality

$$
\text { and Individual Differences, 9,211-216. }
$$

https://doi.org/10.1016/j.paid.2016.05.034

Mottola, G. R. (2014). The Financial Capability of Young Adults - A Generational View. FINRA Foundation Financial Capability Insights.

Nurhayati, L., \& Muflikhati, I. (2020). Child involvement in family financial management and subjective wellbeing of children from the intact and non-intact families. Journal of Consumer Sciences, 5(1), 46-57.

https://doi.org/10.29244/JCS.5.1.46-57

Pham, T. H., Yap, K., \& Dowling, N. A. (2012). The impact of financial management practices and financial attitudes on the relationship between materialism and compulsive buying. Journal of Economic Psychology. https://doi.org/10.1016/j.joep.2011.12.007

Rea, J. K., Zuiker, V. S., \& Mendenhall, T. J. (2016). Money and Emerging Adults: A Glimpse into the Lives of College Couples' Financial Management Practices. Journal of Financial Therapy. https://doi.org/10.4148/1944-9771.1110

Ridhayani, F., \& Johan, I. R. (2020). The Influence of Financial Literacy and Reference Group toward Consumptive Behavior Across Senior High School Students. Journal

$$
\text { of Consumer Sciences, 05(01), 29-45. }
$$

https://doi.org/10.29244/JCS.5.1.29-45

Sachitra, V., \& Bandara, U. (2017). Measuring the academic self-efficacy of undergraduates: The role of gender and academic year experience. International Journal of Educational and Pedagogical Sciences.

Sachitra, V., Wijesinghe, D., \& Gunasena, W. (2019). Exploring undergraduates' moneymanagement life: insight from an emerging economy. Young Consumers, 20(3), 167189. https://doi.org/10.1108/YC-07-2018-00828

Su, W., \& Deng, M. (2012). Survey and Thought of Financial Management and Education in High School Students in Nanjing. Creative Education, 3, 228-231. https://doi.org/10.4236/ce.2012.32036

Sundaram, K., Dwivedi, S., \& Sreenivas, V. (2010). Medical Statistics Principles and Methods (First Edit). New Delhi: B.I Publications Pvt Ltd. 